\title{
Trametes genus, a source of chemical compounds with anticancer activity in human osteosarcoma: A systematic review
}

\author{
Tatiana Muñoz-Castiblanco, Juan Camilo Mejía-Giraldo, Miguel Angel Puertas-Mejía* \\ Grupo de Investigación en Compuestos Funcionales, Facultad de Ciencias Exactas y Naturales, Universidad de Antioquia-UdeA, Medellín, Colombia.
}

\begin{tabular}{lll}
\cline { 1 - 1 } ARTICLE INFO & & ABSTRACT \\
\cline { 1 - 1 } $\begin{array}{l}\text { Received on: } 27 / 04 / 2020 \\
\text { Accepted on: } 12 / 08 / 2020\end{array}$ & $\begin{array}{l}\text { Natural bioactive compounds have aroused great interest for their potential benefits in human health, particularly in the } \\
\text { prevention and treatment of cancer. The aim of this systematic review is to inspect whether bioactive compounds present } \\
\text { in mushrooms of the genus Trametes have shown anticancer activity in human osteosarcoma. According to the PRISMA } \\
\text { (Preferred Reporting Items for Systematic Reviews and Meta-Analyses) parameters, this review was carried out using }\end{array}$ \\
$\begin{array}{ll}\text { Key words: } \\
\text { Trametes, osteosarcoma, }\end{array}$ & $\begin{array}{l}\text { Science Direct, PubMed Central, and Embase as electronic databases to select the articles that evaluated the cytotoxic effects } \\
\text { of extracts or compounds isolated from mushrooms of the genus Trametes in human osteosarcoma. A total of 15 studies } \\
\text { out of } 165 \text { met the inclusion criteria and are included in our systematic review. Among them, six studies evaluated extracts, } \\
\text { mushrooms, polysaccharide, } \\
\text { systematic review. }\end{array}$ & $\begin{array}{l}\text { eight evaluated polysaccharides, and one evaluated tetralin lignans of different species of the genus Trametes. Although } \\
\text { only two research articles evaluated the effects of chemical compounds such as polysaccharides on human osteosarcoma, } \\
\text { all of them have confirmed the potential of compounds present in mushrooms to treat different types of cancer. }\end{array}$
\end{tabular}

\section{INTRODUCTION}

The most common primary bone cancer in children and teenagers is osteosarcoma (Chen et al., 2018a; Suárez et al., 2017). The main difficulty in treating this cancer is that it begins to develop in the skeletal system and it can develop metastasis and spread to other organs of the body, making its timely diagnosis complex. The standard osteosarcoma treatment includes local surgical control, with radical surgery or limb preservation, and the administration of polychemotherapy (methotrexate, doxorubicin, cisplatin, and ifosfamide) (Suárez et al., 2017). The prognosis of patients with osteosarcoma can be improved with the combination of surgery and chemotherapy. However, a considerable number of patients have developed resistance to chemotherapy (Chen et al., 2018b). In addition, some chemotherapeutic agents are not selective since they also attack normal cells and generate toxic side effects (Ferrari and Palmerini, 2007; Zhao et al., 2015b). To overcome this situation, antitumor agents or chemical products

\section{"Corresponding Author}

Miguel Angel Puertas-Mejía, Grupo de Investigación en Compuestos Funcionales, Facultad de Ciencias Exactas y Naturales, Universidad de Antioquia-UdeA, Medellín,Colombia.E-mail:miguel.puertas@udea.edu.co with increased efficiency and reduced toxicity are being developed (Zhao et al., 2015b).

For the treatment of cancer, Chinese medicines have been used as either food ingredients or supplements. Generally, cancer patients use herbal medicines with conventional medical treatment to improve the desired results (Ko et al., 2017). Among these Chinese herbal medicines, mushrooms represent a source of compounds with antioxidant, immunomodulating, anti-inflammatory, antimicrobial, and anticancer properties (Ricciardi et al., 2017). Mushrooms have been consumed for many years because they have a large number of bioactive compounds, including polysaccharides, proteins, and lipids (Wasser, 2011). Specifically, the anticancer potential to treat various types of cancer by some species of the genus Trametes, such as Trametes versicolor (synonym Coriolus versicolor), Trametes gibbosa, Trametes hirsuta, Trametes lactinea, and Trametes robiniophila, has been reported. In general, this anticancer activity has been attributed to chemical compounds such as polysaccharides (He et al., 2018; Ricciardi et al., 2017; Rosendahl et al., 2012; Scarpari et al., 2017; Wang et al., 2017a, 2017b; Zhao et al., 2015a, 2015b) and tetralin lignans (Puri et al., 2006). Mushroom polysaccharides are significant compounds with anticancer, anti-oxidative, antidiabetic, antimicrobial, anti-inflammatory, and immunomodulatory activity. $\beta$-glucan is the main polysaccharide found in mushrooms and it makes up about half the mass of its cell wall (Amirullah et al., 2018). 
T. versicolor essentially contains polysaccharide-K or Krestin (PSK) and polysaccharide peptide (PSP). In PSK, roughly $62 \%$ of the molecule is polysaccharide and $38 \%$ is protein and PSP is a protein-bound polysaccharide (Fritz et al., 2015). PSK has shown anticancer activity in breast, colorectal, and gastrointestinal cancers (Blagodatski et al., 2018; Kiyama, 2017). T. robiniophila has demonstrated an antiproliferative effect on the diversity of tumor cells via inducing apoptosis (Ren et al., 2009; Zhao et al., 2015a). Proteoglycans have been recognized as the principal components answerable for the anticancer activity of $T$. robiniophila (Li et al., 2015; Sun et al., 2013; Zhao et al., 2015b).

In this regard, the aim of this systematic review is to analyze the information from reports which demonstrate the anticancer activity of the bioactive compounds isolated from several species of the genus Trametes on human osteosarcoma.

\section{MATERIALS AND METHODS}

\section{Search terms}

The present systematic review involved research articles from the Science Direct, Pubmed Central and Embase databases from 2000 to May 2019. The search terms were "T. versicolor", "osteosarcoma OR bone cancer OR anticancer", and "bioactive compounds OR metabolites" and the keywords "in vivo OR in vitro" were used as a search strategy. The articles were selected first by the title, then by the summary, and finally by reading the full text. Two relevant articles were found through manual searches in the reference lists.

\section{Inclusion and exclusion criteria}

Finally, the articles were chosen by taking into account some inclusion and exclusion criteria (see Table 1).

\section{Quality evaluation}

The quality of the articles included in this review was systematically evaluated. The quality score was assigned considering the following five items: characterization of extracts or compounds of interest ( 2 points), anticancer tests in vitro, ex vivo, and in vivo ( 2 points for each test), and the use of controls in anticancer tests ( 2 points) for a maximum score of 10 points.

\section{Quality evaluation of the parameters}

\section{Characterization of extracts or compounds of interest}

- If the extract or the compound of interest is not characterized: 0 points.

- If the extract or the compound of interest is characterized by generic tests (presence of carbohydrates, total phenolic content, etc.): 1 point.
- If the extract or the compound of interest is characterized by specific tests (FTIR (Fourier-transform infrared spectroscopy), NMR (Nuclear Magnetic Resonance), etc.): 2 points.

Anticancer tests in vitro

- If in vitro anticancer tests are not performed: 0 points.

- If in vitro anticancer tests are performed: 2 points.

Anticancer tests ex vivo

- If ex vivo anticancer tests are not performed: 0 points.

- If ex vivo anticancer tests are carried out: 2 points.

Anticancer tests in vivo

- If in vivo anticancer tests are not performed: 0 points.

- If in vivo anticancer tests are performed: 2 points.

Use of controls in anticancer tests

- If controls are not used in anticancer tests: 0 points.

- If at least one control is used in anticancer tests (positive control or negative control): 1 point.

- If two controls are used in anticancer tests (positive control and negative control): 2 points.

\section{Quality ranges}

The articles with 8-10, 4-7, and 0-3 points were recognized as high, moderate, and low quality, respectively.

\section{Data extraction}

The information extracted from each study included author name, publication year, country, main objective, and main findings of each research. In order to guarantee the success of the revision process, the data analysis and assessment were carried out by three independent reviewers, who assessed the reproducibility and the probability of bias in each stage of the review.

\section{RESULTS}

\section{Selection of studies}

The initial search through databases identified 343 articles. After removing duplicates, the remaining 165 articles were reviewed based on the title and the abstract by reviewers. A total of 21 articles were reviewed based on full-text availability. Finally, the 15 studies included in our systematic review met the inclusion criteria. Figure 1 shows the flow diagram of the search results.

Table 1. Inclusion and exclusion criteria.

\begin{tabular}{|c|c|c|}
\hline Parameter & Inclusion criteria & Exclusion criteria \\
\hline Language & English & Any other language \\
\hline Type of publication & Research articles & Review articles, editorial material, meeting summaries, letters, publications, and book chapters \\
\hline Characterization & Characterization of extracts or compound of interest & Uncharacterized extracts \\
\hline Type of study & In vitro and/or in vivo & Any other type of study \\
\hline Genus of mushroom & Any species of the Trametes genus & Genus other than Trametes \\
\hline
\end{tabular}




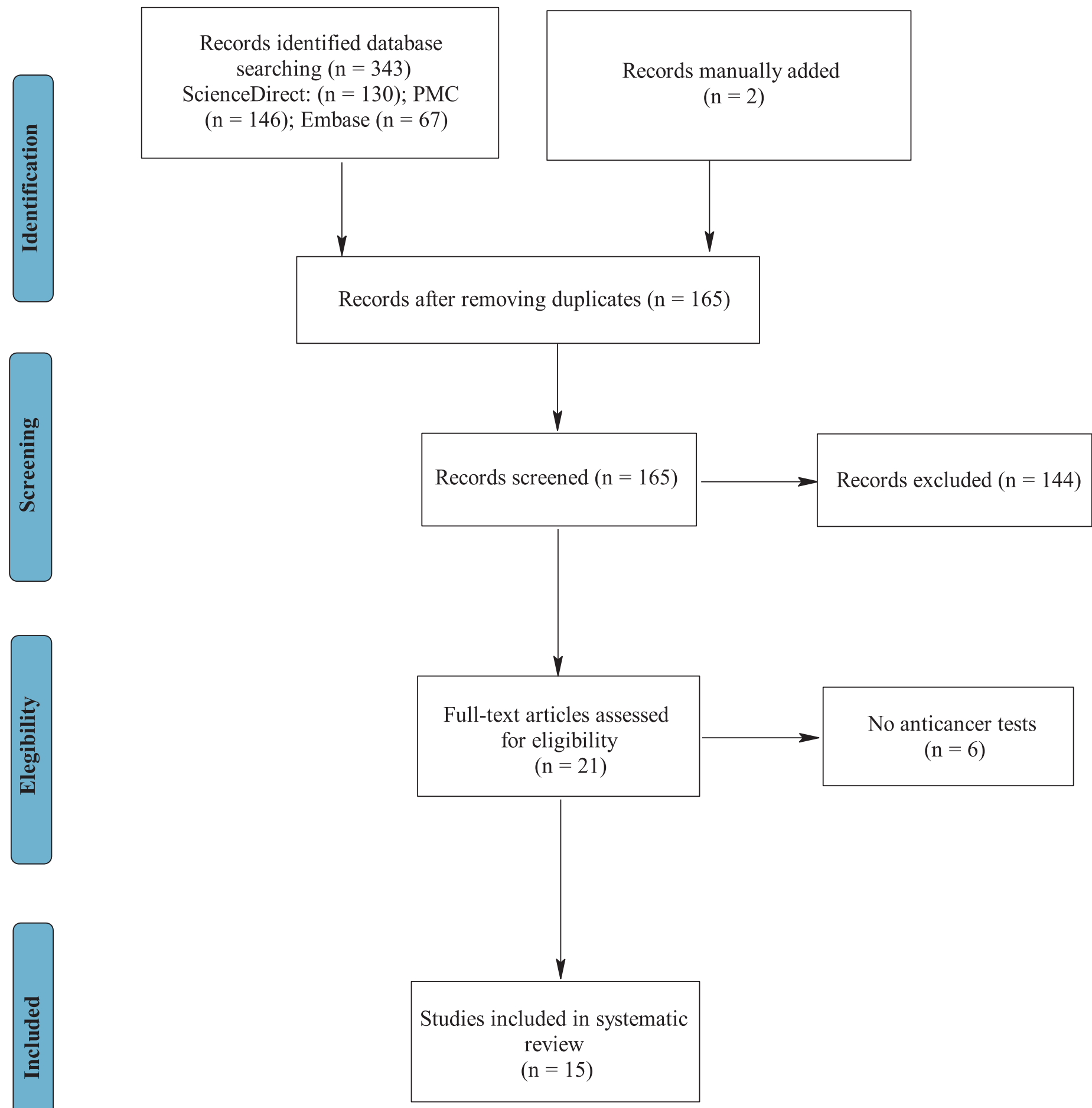

Figure 1. Flow diagram of study selection process.

\section{Characteristics of the studies}

Among the 15 research articles included, 2 studies evaluated the anticancer activity of ethanol extracts of the fruiting body (Janjušević et al., 2018) and basidiocarp and mycelium (Knežević et al., 2018); 4 studies evaluated the activity of a polysaccharide-rich aqueous extract of the fruiting body (Roca-Lema et al., 2019), an aqueous extract of the fruiting body (Ko et al., 2017; Luo et al., 2014), and mycelial biomass (Shnyreva et al., 2018). Moreover, 9 studies evaluated the activity of compounds such as polysaccharides (He et al., 2018; Zhao et al., 2015a, 2015b), PSK (Rosendahl et al., 2012), intracellular protein-polysaccharide (Wang et al., 2017a), 
extracellular polysaccharide (Wang et al., 2017b), Tramesan (Ricciardi et al., 2017; Scarpari et al., 2017), and tetralin lignans (Puri et al., 2006). Table 2 describes some features of each study, involving the year of publication, country, objective, extract or compound of interest, and the species of the mushrooms used.

\section{Results of individual studies}

All studies evaluate the cytotoxic effects of extracts or derivate compounds from different species of the genus Trametes in cell lines of various types of cancer. In some of these research articles, the mechanism underlying these effects was identified. Table 3 shows the anticancer assays and the principal findings of the individual reports.

\section{Evaluation of the quality of the studies}

Table 4 shows the quality assessment for each study based on the inclusion and exclusion criteria. The total average score was $4.8 \pm 1.0$. Hence, for articles where extracts were evaluated,

Table 2. Main characteristics of the included studies.

\begin{tabular}{|c|c|c|c|c|c|}
\hline Reference & Year & Country & Objective & $\begin{array}{l}\text { Extracts or compounds of } \\
\text { interest }\end{array}$ & Species \\
\hline Roca-Lema et al., 2019 & 2019 & Spain & $\begin{array}{l}\text { To appraise the anticancer activity of } \\
\text { mushroom polysaccharide extracts on human } \\
\text { colon cancer cells }\end{array}$ & $\begin{array}{l}\text { Polysaccharide-rich aqueous } \\
\text { extract of the fruiting body }\end{array}$ & T. versicolor and Grifola frondosa \\
\hline He et al., 2018 & 2018 & China & $\begin{array}{l}\text { To isolate, purify, characterize, and evaluate } \\
\text { antioxidant and antitumor activities of the } \\
\text { polysaccharide fractions from T. lactinea } \\
\text { (Berk.) Pat }\end{array}$ & Polysaccharide & T. lactinea (Berk.) Pat \\
\hline Janjušević et al., 2018 & 2018 & Serbia & $\begin{array}{l}\text { To investigate the biological activities of } \\
\text { ethanol extracts from } T \text {. versicolor to } \\
\text { develop food supplements }\end{array}$ & Ethanol extract of fruiting body & T. versicolor \\
\hline Knežević et al., 2018 & 2018 & Serbia & $\begin{array}{l}\text { To explain the biological activities of the } \\
\text { ethanol extracts of some Trametes species }\end{array}$ & $\begin{array}{l}\text { Ethanol extracts of basidiocarp } \\
\text { and mycelium }\end{array}$ & $\begin{array}{l}\text { T. gibbosa, T. hirsuta, and } \\
\text { T. versicolor }\end{array}$ \\
\hline Shnyreva et al., 2018 & 2018 & Russia and others & $\begin{array}{l}\text { To examine the cytotoxicity and } \\
\text { antiproliferative activity of aqueous extracts } \\
\text { of mushrooms for their possible use in } \\
\text { biomedicine }\end{array}$ & $\begin{array}{l}\text { Aqueous extracts from mycelial } \\
\text { biomass }\end{array}$ & $\begin{array}{l}\text { T. versicolor, Fomes fomentarius, } \\
\text { Fomitopsis pinicola, Trichaptum } \\
\text { biforme, Inonotus obliquus, and } \\
\text { Coniophora puteana }\end{array}$ \\
\hline Koet al., 2017 & 2017 & Hong Kong & $\begin{array}{l}\text { To evaluate aqueous extract of } \\
\text { T. versicolor-metronomic zoledronic acid } \\
\text { (mZOL) interaction in preventing cancer } \\
\text { propagation, metastasis, and bone destruction }\end{array}$ & $\begin{array}{l}\text { Aqueous extract of fruiting body } \\
\text { polysaccharides and triterpenoid }\end{array}$ & T. versicolor \\
\hline Ricciardi et al., 2017 & 2017 & Italy & $\begin{array}{l}\text { To evaluate the antiproliferative effects of } \\
\text { Tramesan on leukemia cells }\end{array}$ & Tramesan & T. versicolor \\
\hline Scarpari et al., 2017 & 2017 & Italy & $\begin{array}{l}\text { To identify and partially characterize a } \\
\text { biologically active fraction (Tramesan) of the } \\
\text { T. versicolor filtrate }\end{array}$ & Tramesan & T. versicolor \\
\hline Wang et al., 2017a & 2017 & China & $\begin{array}{l}\text { To investigate the effect of tyrosol on cell } \\
\text { growth of } T \text {. versicolor and intracellular } \\
\text { protein-polysaccharides production }\end{array}$ & $\begin{array}{l}\text { Intracellular protein- } \\
\text { polysaccharide }\end{array}$ & T. versicolor \\
\hline Wang et al., 2017b & 2017 & China & $\begin{array}{l}\text { To investigate the effect of farnesol on } \\
\text { intracellular polysaccharide biosynthesis } \\
\text { and mycelial morphology of } T \text {. versicolor } \\
\text { and how they affect the extracellular } \\
\text { polysaccharide production }\end{array}$ & $\begin{array}{l}\text { Extracellular } \\
\text { polysaccharide }\end{array}$ & T. versicolor \\
\hline Zhao et al., 2015a & 2015 & China & $\begin{array}{l}\text { To evaluate the cytotoxic effects of the } \\
\text { purified polysaccharide from } T \text {. robiniophila } \\
\text { on human osteosarcoma U-2 OS cell and to } \\
\text { identify its mechanism of action }\end{array}$ & Polysaccharide & T. robiniophila \\
\hline Zhaoet al., 2015b & 2015 & China & $\begin{array}{l}\text { To investigate the effects of one } \\
\text { polysaccharide from } T \text {. robiniophila on } \mathrm{U}-2 \\
\text { OS xenografts tumor growth in vivo and to } \\
\text { identify the possible mechanism }\end{array}$ & Polysaccharide & T. robiniophila \\
\hline Luo et al., 2014 & 2014 & Hong Kong & $\begin{array}{l}\text { To explore the antimigration and anti- } \\
\text { invasion capabilities of } C \text {. versicolor extract } \\
\text { in } 4 \mathrm{~T} 1 \text { cells in vitro and to evaluate in vivo } \\
\text { some biological activities of } C \text {. versicolor } \\
\text { extract in a mouse } 4 \mathrm{~T} 1 \text {-tumor bearing model }\end{array}$ & $\begin{array}{l}\text { Aqueous extract of fruiting } \\
\text { body the major components are } \\
\text { polysaccharides }\end{array}$ & C. versicolor \\
\hline Rosendahl et al., 2012 & 2012 & Sweden & $\begin{array}{l}\text { To establish the direct effects of PSK on } \\
\text { epithelial tumor cells and to explore the } \\
\text { mechanisms of action }\end{array}$ & PSK & T. versicolor \\
\hline Puri et al., 2006 & 2006 & India & $\begin{array}{l}\text { To isolate, identify, and characterize the } \\
\text { aryl tetralin lignans produced by the fungal } \\
\text { endophyte } T \text {. hirsuta }\end{array}$ & $\begin{array}{l}\text { Tetralin lignans: podophyllotoxin } \\
\text { and its glycoside }\end{array}$ & T. hirsuta \\
\hline
\end{tabular}


Table 3. Anticancer tests and main findings of the individual studies.

\begin{tabular}{|c|c|c|c|}
\hline \multirow{2}{*}{ Reference } & \multicolumn{2}{|c|}{ Anticancer tests } & \multirow{2}{*}{ Main findings } \\
\hline & Methods & Controls & \\
\hline Roca-Lema et al., 2019 & $\begin{array}{l}\text { In vitro: } 3 \text {-(4,5-dimethylthiazol- } \\
\text { yl)-2,5-diphenyltetrazolium } \\
\text { bromide (MTT) assay }\end{array}$ & $\begin{array}{l}\text { Negative control } \\
\text { The combination of polysaccharide-rich } \\
\text { extracts with 5-fluorouracil (5-Fu) } \\
\text { Positive control: } 5 \text {-Fu }\end{array}$ & $\begin{array}{l}\text { Polysaccharide-rich extracts from } T \text {. versicolor and } G \text {. frondosa } \\
\text { showed cytotoxic effects in LoVo and HT- } 29 \text { human colon cancer cells. } \\
\text { Moreover, these extracts inhibited oncogenic potential, cell migration, } \\
\text { and invasion in colon cancer cells. The combination of polysaccharide- } \\
\text { rich extracts with 5-Fu increased cell cytotoxicity }\end{array}$ \\
\hline He et al., 2018 & $\begin{array}{l}\text { In vitro: } \mathrm{MTT} \text { assay }{ }^{\mathrm{a}} \text { and lactic } \\
\text { dehydrogenase }(\mathrm{LDH}) \text { assay }^{\mathrm{b}}\end{array}$ & $\begin{array}{l}\text { Negative control } \\
\text { Positive control: } 5 \text {-Fu }\end{array}$ & $\begin{array}{l}\text { The } T \text {. lactinea polysaccharide fraction with the average molecular } \\
\text { weight of } 443.19 \mathrm{KDa} \text { (TLP-1) showed anticancer activity in HepG-2 } \\
\text { cells, which was associated with a decrease in cell proliferation and an } \\
\text { increase in LDH leakage and apoptotic cell population. Additionally, } \\
\text { TLP-1 presented antioxidant activity }\end{array}$ \\
\hline Janjušević et al., 2018 & In vitro: $\mathrm{MTT}$ assay ${ }^{\mathrm{a}}$ & Negative control & $\begin{array}{l}\text { The ethanol extracts of fruiting bodies from } T \text {. versicolor exhibited } \\
\text { cytotoxicity in MCF- } 7 \text { and HepG } 2 \text { tumor cell lines. This cytotoxicity } \\
\text { may be due to the presence of gentisic, syringic, and protocatechuic } \\
\text { acids }\end{array}$ \\
\hline Knežević et al., 2018 & In vitro: $\mathrm{MTT}$ assay ${ }^{\mathrm{a}}$ & $\begin{array}{l}\text { Negative control } \\
\text { Positive control: } \text { cis- } \\
\text { diamminedichloroplatinum (cis-DDP) } \\
\text { and doxorubicin }\end{array}$ & $\begin{array}{l}\text { The mycelium extracts from T. gibbosa, T. hirsuta, and T. versicolor } \\
\text { showed stronger cytotoxic effects than the basidiocarp extracts in } \\
\text { cell lines of human cervical adenocarcinoma (HeLa), human colon } \\
\text { carcinoma (LS174), and human lung adenocarcinoma (A549). These } \\
\text { results can be related to a synergistic action of triterpenes, sugars, and } \\
\text { polyphenols. Furthermore, the basidiocarps and mycelia extracts of } \\
\text { these Trametes species inhibited the activity of acetylcholinesterase and } \\
\text { tyrosinase }\end{array}$ \\
\hline Shnyreva et al., 2018 & In vitro: $\mathrm{MTT}$ assay & Unspecified control & $\begin{array}{l}\text { The methanol-chloroform (1:1) extract of mycelial biomass from } T \text {. } \\
\text { versicolor (strain It-1) inhibited the growth of lung, breast, cervix, and } \\
\text { colon solid tumors. Also, the hot water extracts of mycelial biomass } \\
\text { from T. versicolor, Coniophora puteana, and Fomes fomentarius } \\
\text { showed antiproliferative effect on leukemia cell lines (Jukart, K562, } \\
\text { and THP-1) }\end{array}$ \\
\hline Ko et al., 2017 & $\begin{array}{l}\text { In vivo: the bioluminescence } \\
\text { measurements according to the } \\
\text { average radiance }\end{array}$ & $\begin{array}{l}\text { Negative control } \\
\text { Positive control: } \mathrm{mZOL}\end{array}$ & $\begin{array}{l}\text { The combination of C. versicolor aqueous extract and mZOL inhibited } \\
\text { cell proliferation and osteogenesis on breast cancer cells MDA-MB- } \\
231 \text {-TXSA. This combination decreased tumor growth and preserved } \\
\text { bone integrity in an intratibial breast tumor model }\end{array}$ \\
\hline Ricciardi et al., 2017 & $\begin{array}{l}\text { In vitro: trypan blue dye exclusion } \\
\text { assay }^{\mathrm{a}}\end{array}$ & Negative control & $\begin{array}{l}\text { Tramesan inhibited the growth of human myeloid (OCI-AML3) and } \\
\text { lymphoid (Jurkat) cell lines. Besides, the antiproliferative effect of } \\
\text { Tramesan on AML cell lines was determined to be related to the } \\
\text { induction of apoptosis }\end{array}$ \\
\hline Scarpari et al., 2017 & $\begin{array}{l}\text { In vitro: counting the number of } \\
\text { viable cells with light microscopy }\end{array}$ & Negative control & $\begin{array}{l}\text { Tramesan showed acytotoxic effect on murine cell lines of melanoma } \\
\text { (B16-F10). Moreover, this compound can act as a proantioxidant } \\
\text { molecule in different organisms }\end{array}$ \\
\hline Wang et al., 2017a & In vitro: $\mathrm{MTT}$ assay ${ }^{\mathrm{a}}$ & Negative control & $\begin{array}{l}\text { The production of intracellular protein-polysaccharide (IPS) from } T \text {. } \\
\text { versicolor was stimulated and improved in the presence of tyrosol. } \\
\text { Besides, an increase in the total carbohydrate, protein, and glucose } \\
\text { contents of IPS was observed, which was related to its strong antitumor } \\
\text { activity. The antitumor activity of IPS was identified to occur through } \\
\text { cell cycle arrest and an increase in apoptosis }\end{array}$ \\
\hline Wang et al., 2017b & In vitro: $\mathrm{MTT}$ assay ${ }^{\mathrm{a}}$ & Negative control & $\begin{array}{l}\text { The production of extracellular polysaccharide (EPS) from } T \text {. } \\
\text { versicolor was stimulated in the presence of farnesol. Farnesol altered } \\
\text { the physicochemical properties of EPS. Furthermore, under farnesol } \\
\text { stimulation, it was observed that EPS had more carbohydrate and uronic } \\
\text { acid contents, and it also exhibited enhanced antioxidant and antitumor } \\
\text { activities }\end{array}$ \\
\hline Zhao et al., 2015a & In vitro: $\mathrm{MTT}$ assay ${ }^{\mathrm{a}}$ & Negative control & $\begin{array}{l}\text { T. robiniophila polysaccharide inhibited the proliferation of human } \\
\text { osteosarcoma cell lines (OS U-2) through a mitochondria-dependent } \\
\text { apoptotic pathway. This mechanism was related to an increase in the } \\
\text { Bax/Bcl-2 ratio, loss of mitochondrial membrane potential }(\Delta \psi \mathrm{m}) \text {, } \\
\text { release of cytochrome } \mathrm{c} \text {, activation of caspase- } 9 \text { and caspase- } 3 \text {, } \\
\text { cleavage of PARP, and inhibition of MTDH expression }\end{array}$ \\
\hline Zhao et al., 2015b & $\begin{array}{l}\text { In vivo: measurementof tumor } \\
\text { weight and tumor volume at the } \\
\text { end of the experiment }\end{array}$ & Negative control & $\begin{array}{l}\text { T. robiniophila polysaccharide was orally administered to nude mice } \\
\text { with xenografted U- } 2 \text { OS osteosarcoma tumors. The mechanism of } \\
\text { suppression of tumor growth in mice occurred via a mitochondria- } \\
\text { dependent apoptotic pathway, which was related to increased Bax/Bcl- } 2 \\
\text { ratio, activation of caspase- } 9 \text { and caspase- } 3 \text {, repression of MTDH, and } \\
\text { the cleavage of PARP }\end{array}$ \\
\hline Luo et al., 2014 & $\begin{array}{l}\text { In vitro: } \mathrm{MTT} \text { assay } \\
\text { In vivo: measurement of tumor } \\
\text { weight at the end of the experiment }\end{array}$ & $\begin{array}{l}\text { Negative control } \\
\text { Positive control: doxorubicin (DOX) }\end{array}$ & $\begin{array}{l}\text { The aqueous extract of } C \text {. versicolor showed an antitumor and } \\
\text { antimetastatic effect, and a bone protective effect against osteolysis } \\
\text { induced by breast cancer. These results were supported by in vitro 4T1 } \\
\text { cell migration and invasion inhibition and in vivo tumor weight and } \\
\text { reducing lung metastasis in mice with } 4 \mathrm{~T} 1 \text { orthotopic tumors }\end{array}$ \\
\hline
\end{tabular}




\begin{tabular}{|c|c|c|c|}
\hline \multirow{2}{*}{ Reference } & \multicolumn{2}{|c|}{ Anticancer tests } & \multirow{2}{*}{ Main findings } \\
\hline & Methods & Controls & \\
\hline Rosendahl et al., 2012 & In vitro: $\mathrm{MTT}$ assay ${ }^{\mathrm{a}}$ & Negative control & $\begin{array}{l}\text { PSK inhibited the growth of human pancreatic cancer cell lines } \\
\text { BxPC-3, PANC-1, MIAPaCa-2, and AsPC-1. Furthermore, the } \\
\text { antiproliferative mechanism of PSK was determined to be related to } \\
\text { cell cycle arrest and apoptosis induction, as evidenced by the increased } \\
\text { cell cycle regulation p } 21^{\text {WAF/Cipl }} \text { and pro-apoptotic protein Bax levels. An } \\
\text { additive effect on growth inhibition was also observed when PSK and } \\
\text { gemcitabine were administered as combined treatment }\end{array}$ \\
\hline Puri et al., 2006 & $\begin{array}{l}\text { In vitro: propidium iodide }(\mathrm{PI}) \\
\text { exclusion and Hoechst-33342 (H- } \\
\text { 33342) uptake }\end{array}$ & Unspecified control & $\begin{array}{l}\text { The tetralin lignans (podophyllotoxin and its glycoside) produced by } \\
\text { T. hirsuta showed anticancer activity in human malignant glioma cells } \\
\text { (U87). Also, they presented antioxidant and radioprotective activity }\end{array}$ \\
\hline
\end{tabular}

MTT $=([3-(4,5$-dimethylthiazol-yl)-2,5-diphenyltetrazolium bromide $])$ assay; $\mathrm{LDH}=($ lactic dehydrogenase $)$ assay; negative control $=$ test without the extract or compound of interest. ${ }^{\mathrm{a}}$ Cell viability; ${ }^{\mathrm{b}}$ Cytotoxic effects.

Table 4. Quality assessment of studies.

\begin{tabular}{|c|c|c|c|c|c|c|}
\hline \multirow{2}{*}{ Author } & \multirow{2}{*}{ Characterization of extracts or compounds of interest } & \multicolumn{3}{|c|}{ Anticancer tests } & \multirow{2}{*}{ Use of controls } & \multirow{2}{*}{ Total } \\
\hline & & In vitro & Ex vivo & In vivo & & \\
\hline Roca-Lema et al., 2019 & 1 & 2 & 0 & 0 & 1 & 4 \\
\hline He et al., 2018 & 2 & 2 & 0 & 0 & 2 & 6 \\
\hline Janjušević et al., 2018 & 1 & 2 & 0 & 0 & 1 & 4 \\
\hline Knežević et al., 2018 & 2 & 2 & 0 & 0 & 2 & 6 \\
\hline Shnyreva et al., 2018 & 1 & 2 & 0 & 0 & 1 & 4 \\
\hline Ko et al., 2017 & 1 & 0 & 0 & 2 & 2 & 5 \\
\hline Ricciardi et al., 2017 & 0 & 2 & 0 & 0 & 1 & 3 \\
\hline Scarpari et al., 2017 & 2 & 2 & 0 & 0 & 1 & 5 \\
\hline Wang et al., 2017a & 2 & 2 & 0 & 0 & 1 & 5 \\
\hline Wang et al., 2017b & 2 & 2 & 0 & 0 & 1 & 5 \\
\hline Zhao et al., 2015a & 2 & 2 & 0 & 0 & 1 & 5 \\
\hline Zhao et al., 2015b & 2 & 0 & 0 & 2 & 1 & 5 \\
\hline Luo et al., 2014 & 1 & 2 & 0 & 2 & 2 & 7 \\
\hline Rosendahl et al., 2012 & 0 & 2 & 0 & 0 & 1 & 3 \\
\hline Puri et al., 2006 & 2 & 2 & 0 & 0 & 1 & 5 \\
\hline
\end{tabular}

Mean: $4.8 \pm 1.0$.

an average score of $5.0 \pm 1.2$ was presented and for studies that evaluated specific compounds, such as polysaccharides, Tramesan, and tetralin lignans, an average quality score of $4.7 \pm 1.0$ was found. Although a high level of quality was not observed concerning the parameters defined by us, these results showed a satisfactory level of quality to validate the results and the conclusions.

\section{DISCUSSION}

\section{Summary of results}

This research intended to carry out a systematic review of the evidence on the anticancer activity of chemical compounds isolated from Trametes in human osteosarcoma. It should be noted that only two articles evaluated the in vitro (Zhao et al., 2015a) and in vivo (Zhao et al., 2015b) activity of polysaccharides isolated from $T$. robiniophila in human osteosarcoma. In these studies, the results suggested that polysaccharide-induced apoptosis occurs through a mitochondria-mediated intrinsic apoptotic pathway. However, in all the articles, the potential of the bioactive compounds present in mushrooms like Trametes to treat different types of cancer is confirmed; this potential could be attributed to the compounds like polysaccharides that presented a wide variety of mechanisms of anticancer activity. Among these mechanisms are the depolarization of the mitochondrial membrane, the cell cycle arrest, the nitric oxide pathway, and the immunomodulation (Khan et al., 2019).

The proteins implicated in proliferative pathways may induce or stop the apoptosis process in cells, thus allowing manipulation of the cell cycle. Apoptosis or programmed cell death occurs mostly through the caspase cascade (Pucci et al., 2003). On the other hand, depolarization of the mitochondrial membrane produces the release of cytochrome $\mathrm{c}$ into the cytoplasm. This release leads to the formation of an apoptosome complex, which produces the activation of caspases (caspase- 9 and caspase-3), a group of cysteine proteases, which initiate apoptosis (Tian et al., 2016). Furthermore, an increase in the ratio of Bax/Bal2 (apoptosis inducer/apoptosis suppressor) is related to apoptosis induction (Khan et al., 2019).

Several polysaccharides boost macrophages to produce NO (Nitric oxide) by positively regulating the inducible NO synthase activity. NO can induce cytotoxicity by inhibiting essential enzymes, depleting antioxidant stores, inducing lipid 
peroxidation, and causing DNA damage. Also, most of these polysaccharides function independently to give anticancer activity, generating the release of cytokines and improving the expression of lymphocyte. It has also been indicated that the intensification in NO production generates the death of tumor cells via the caspase pathway. Furthermore, the polysaccharides have immunostimulant activity (Bao et al., 2013; Jiang et al., 2014; Khan et al., 2019)

\section{Explanation of the results}

Complete research articles incorporated in this systematic review indicated that extracts, as well as isolated compounds from different species of Trametes, displayed cytotoxic potential in various types of cancer. The ethanol extract obtained from fruiting bodies from $T$. versicolor blocked the proliferation in vitro of human breast adenocarcinoma (MCF-7) and human hepatocellular carcinoma (HepG2) cell lines (Janjušević et al., 2018). Similarly, the ethanol extracts of basidiocarp and mycelium from T. gibbosa, $T$. hirsuta, and $T$. versicolor revealed in vitro cytotoxic activity against human cervix adenocarcinoma (HeLa), human colon carcinoma (LS174), and human lung adenocarcinoma (A549) cell lines (Knežević et al., 2018). Results observed in ethanol extracts could happen via the cell cycle arrest as previously stated (Harhaji et al., 2008; Hsieh et al., 2002).

Likewise, the aqueous extracts of the fruiting bodies from C. versicolor suppress in vitro $4 \mathrm{~T} 1$ cell migration and invasion; moreover, these extracts decreased in vivo tumor weight and lung metastasis in BALB/c mice bearing orthotopic 4T1 tumors (Luo et al., 2014). The aqueous extracts of mycelial biomass from $T$. versicolor and other mushrooms exhibited in vitro cytotoxic effects against human solid tumor cell lines such as A-549 and SW1573 (lung), HBL-100 and T-47D (breast), HeLa (cervix), and WiDr (colon) (Shnyreva et al., 2018). The grouping of aqueous extracts and chemotherapeutic agents (Roca-Lema et al., 2019) or metronome zoledronic acid (mZOL) (Ko et al., 2017) has also been described to increase the biological activity thereof. For example, the mixture of polysaccharide-rich aqueous extracts from T. versicolor and $G$. frondosa with 5-fluorouracil improved the in vitro cytotoxic effects in LoVo and HT-29 human colon cancer cells (Roca-Lema et al., 2019); the mixing of the aqueous extract from $T$. versicolor with $\mathrm{mZOL}$ avoided in vivo breast cancer propagation, metastasis, and bone destruction (Ko et al., 2017).

Furthermore, a fraction of polysaccharide isolated from the liquid culture of $T$. versicolor (Tramesan) exhibited in vitro antiproliferative effects in cell lines of murine melanoma B16-F10 (Scarpari et al., 2017), human myeloid (OCI-AML3), and lymphoid (Jurkat) (Ricciardi et al., 2017). This antiproliferative effect of Tramesan is associated with cell cycle arrest and apoptosis induction, although it has also been described that the effect of numerous fungal polysaccharides is associated with oxidative stress (Queiroz et al., 2015). In addition, cell cycle arrest has been assumed to occur by the inhibition of cyclin-dependent kinases and activation of cell cycle checkpoints, which lead to cell death (Khan et al., 2019). Also, in vitro antitumor activity of an intracellular protein-polysaccharide (Wang et al., 2017a) and extracellular polysaccharide (Wang et al., 2017b) obtained from $T$. versicolor against HeLa cells was estimated. The results showed that the growth inhibitory effect on HeLa cells occurs via cell cycle arrest with cell accumulation in $\mathrm{S}$ phase and an increase in apoptotic cells (Wang et al., 2017a). On the other hand, it was shown that tetralin lignans isolated from $T$. hirsuta displayed in vitro cytotoxic effects in human malignant glioma cells (U87) (Puri et al., 2006).

Moreover, the polysaccharides isolated from T. lactinea (Berk.) Pat exhibited in vitro antitumor activity on HepG-2 and normal hepatocyte L-02 cells, which was evidenced with the decreased cell proliferation and the increased leakage of cytoplasmic lactate dehydrogenase and the number of apoptotic cells (He et al., 2018). Also, it was shown that the PSK isolated from T. versicolor inhibited cell proliferation by cell cycle arrest and induction of apoptosis in the human pancreatic cancer cells BxPC-3, PANC-1, MIAPaCa-2, and AsPC-1 (Rosendahl et al., 2012).

Furthermore, the polysaccharides obtained from the fruiting bodies of $T$. robiniophila showed the ability to reduce in vitro cell proliferation in human osteosarcoma U-2 OS cells (Zhao et al., 2015a) and human osteosarcoma xenograft tumor growth in vivo (Zhao et al., 2015b). These polysaccharides induced apoptosis in tumor tissues and U-2 OS cells through a mitochondriadependent pathway, as demonstrated by the increase in Bax/Bcl2 ratio, activation of caspase- 9 and caspase- 3 , and cleavage of poly(ADP-ribose)polymerase (PARP). The results indicate that the polysaccharides from $T$. robiniophila could be used as a possible chemotherapeutic agent athwart human osteosarcoma (Zhao et al., $2015 \mathrm{a}, 2015 \mathrm{~b}$ ). These two studies have shown enough evidence of the anticancer potential in isolated compounds from mushrooms of the genus Trametes to treat human osteosarcoma. Finally, the analysis of this systematic review showed an invaluable potential of extracts and isolated compounds from the genus Trametes as anticancer agents.

Lastly, mushroom $\beta$-glucans contain linear $\beta$ - $(1 \rightarrow 3)$ linked backbones with $\beta-(1 \rightarrow 6)$-linked side chains of varying length and distribution. Some structural variations include $1 \rightarrow 4$ linkages, $\alpha$-glucan moieties, protein complexes, and sugar type. Mushroom $\beta$-glucans present a great variety of biological activities, highlighting their anticancer and immunomodulatory activity. These properties could be associated with their ability to induce biological responses by binding to membrane receptors. $\beta$-glucans can induce the immune system since they are not synthesized by humans and therefore they are recognized as strange agents (Phan et al., 2018).

\section{CONCLUSION}

The present systematic review has examined the current evidence on the anticancer activity of chemical compounds from mushrooms of the genus Trametes in human osteosarcoma. Finally, 15 studies were included, in which 6 of them assessed extracts, 8 studies evaluated polysaccharides, and 1 study estimated tetralin lignans of different species of the genus Trametes. The results and analysis of the articles involved in this review have provided enough indication of the anticancer potential of isolated compounds from different species of the genus Trametes. However, studies relating to the anticancer potential of bioactive mushrooms compounds in human osteosarcoma are incipient yet. These findings leave an open gap to continue with studies that help to address this health problem as well as understand the mechanisms by which these natural products have beneficial effects on the treatment of different types of cancer. 


\section{ACKNOWLEDGMENTS}

Muñoz-Castiblanco T. acknowledges the doctoral fellowship granted by Colciencias (Programa de Becas de Excelencia Doctoral del Bicentenario, 2019, Primera Corte). This work was partially supported by CODI, University of Antioquia (Project no. 2019-25210).

\section{CONFLICT OF INTEREST}

The authors declare that they have no conflicts of interest.

\section{FUNDING}

None.

\section{REFERENCES}

Amirullah NA, Zainal Abidin N, Abdullah N. The potential applications of mushrooms against some facets of atherosclerosis: a review. Food Res Int, 2018; 105:517-36.

Bao X, Yuan H, Wang C, Liu J, Lan M. Antitumor and immunomodulatory activities of a polysaccharide from Artemisia argyi. Carbohydr Polym, 2013; 98(1):1236-43.

Blagodatski A, Yatsunskaya M, Mikhailova V, Tiasto V, Kagansky Al, Katanaev V. Medicinal mushrooms as an attractive new source of natural compounds for future cancer therapy. Oncotarget, 2018; 9(49):29259-74.

Chen D, Zhao Z, Huang Z, Chen DC, ZhuXX, Wang YZ, Yan YW, Tang S, Madhavan S, Ni W, Huang ZP, Li W, Ji W, Shen H, Lin S, Jiang YZ. Super enhancer inhibitors suppress MYC driven transcriptional amplification and tumor progression in osteosarcoma. Bone Res, 2018a; 6(1):1-7.

Chen Y, Wang S, Geng B, Yi Z. Pelargonidin induces antitumor effects in human osteosarcoma cells via autophagy induction, loss of mitochondrial membrane potential, G2/M cell cycle arrest and downregulation of PI3K/AKT signalling pathway. J BUON, 2018b; 23(3):735-40.

Ferrari S, Palmerini E. Adjuvant and neoadjuvant combination chemotherapy for osteogenic sarcoma. Curr Opin Oncol, 2007; 19(4):341-6.

Fritz H, Fernandes R, Seely D, Cooley K, Ishii M, Kennedy DA, Fritz H, Fergusson D. Polysaccharide K and Coriolus versicolor extracts for lung cancer. Integr Cancer Ther, 2015; 14(3):201-11.

Harhaji L, Mijatović S, Maksimović-Ivanić D, Stojanović I, Momčilović M, Maksimović V, Tufegdžić S, Marjanović Ž, MostaricaStojković M, Vučinić Ž, Stošić-Grujičić S. Anti-tumor effect of Coriolus versicolor methanol extract against mouse B16 melanoma cells: in vitro and in vivo study. Food Chem Toxicol, 2008; 46(5):1825-33.

He N, Tian L, Zhai X, Zhang X, Zhao Y. Composition characterization, antioxidant capacities and anti-proliferative effects of the polysaccharides isolated from Trametes lactinea (Berk.) Pat Int J Biol Macromol, 2018; 115:114-23.

Hsieh TC, Kunicki J, Darzynkiewicz Z, Wu JM. Effects of extracts of Coriolus versicolor (I'm-Yunity ${ }^{\mathrm{TM}}$ ) on cell-cycle progression and expression of interleukins-1B, -6 , and -8 in promyelocytic HL-60 leukemic cells and mitogenically stimulated and nonstimulated human lymphocytes. J Altern Complement Med, 2002; 8:591-602.

Janjušević L, Pejin B, Kaišarević S, Gorjanović S, Pastor F, Tešanović K, Karaman M. Trametes versicolor ethanol extract, a promising candidate for health-promoting food supplement. Nat Prod Res, 2018; 32(8): 963-7.

Jiang J, Meng FY, He Z, Ning YL, Li XH, Song H, Wang J, Zhou R. Sulfated modification of longan polysaccharide and its immunomodulatory and antitumor activity in vitro. Int J Biol Macromol, $2014 ; 67: 323-9$.

Khan T, Date A, Chawda H, Patel K. Polysaccharides as potential anticancer agents - A review of their progress. Carbohydr Polym, 2019; 210:412-28.
Kiyama R. DNA microarray-based screening and characterization of traditional Chinese medicine. Microarrays, 2017; 6(1):4.

Knežević A, Stajić M, Sofrenić I, Stanojković T, Milovanović I, Tešević V, Vukojević J. Antioxidative, antifungal, cytotoxic and antineurodegenerative activity of selected Trametes species from Serbia PLoS One, 2018; 13(8):1-18.

Ko CH, Yue GGL, Gao S, Luo KW, Siu WS, Shum WT, Shiu HT, Lee JKM, Li G, Leung PC, Evdokiou A, Lau CBS. Evaluation of the combined use of metronomic zoledronic acid and Coriolus versicolor in intratibial breast cancer mouse model. J Ethnopharmacol, 2017; 204:77-85.

Li C, Wu X, Zhang H, Yang G, Hao M, Sheng S, Sun Y, Long J, $\mathrm{Hu}$ C, Sun X, Li L, Zheng J. A Huaier polysaccharide inhibits hepatocellular carcinoma growth and metastasis. Tumour Biol, 2015; 36(3):1739-45.

Luo KW, Yue GGL, Ko CH, Lee JKM, Gao S, Li LF, Li G, Fung $\mathrm{KP}$, Leung PC, Lau CBS. In vivo and in vitro anti-tumor and anti-metastasis effects of Coriolus versicolor aqueous extract on mouse mammary 4T1 carcinoma. Phytomedicine, 2014; 21(8):1078-87.

Phan CW, Tan EYY, Sabaratnam V. Bioactive molecules in edible and medicinal mushrooms for human wellness. In: Mérillon JM., Ramawat K. (eds.). Bioactive molecules in food. Reference series in phytochemistry, Springer, Cham, Switzerland, 2018

Pucci B, Kasten M, Giordano A. Cell cycle and apoptosis. Cell Prolif, 2003; 36(3):165-75.

Puri SC, Nazir A, Chawla R, Arora R, Riyaz-ul-Hasan S, Amna T, Ahmed B, Verma V, Singh S, Sagar R, Sharma A, Kumar R, Sharma RK, Qazi GN. The endophytic fungus Trametes hirsuta as a novel alternative source of podophyllotoxin and related aryl tetralin lignans. J Biotechnol, 2006; 122(4):494-510.

Queiroz EAIF, Fortes ZB, Da Cunha MAA, Barbosa AM, Khaper N, Dekker RFH. Antiproliferative and pro-apoptotic effects of three fungal exocellular $\beta$-glucans in MCF-7 breast cancer cells is mediated by oxidative stress, AMP-activated protein kinase (AMPK) and the Forkhead transcription factor, FOXO3a. Int J Biochem Cell Biol, $2015 ; 67: 14-24$.

Ren J, Zheng C, Feng G, Liang H, Xia X, Fang J, Duan X, Zhao H. Inhibitory effect of extract of fungi of Huaier on hepatocellular carcinoma cells. J Huazhong Univ Sci Technol, 2009; 29(2):198-201.

Ricciardi MR, Licchetta R, Mirabilii S, Scarpari M, Parroni A, Fabbri AA, Cescutti P, Reverberi M, Fanelli C, Tafuri A. Preclinical antileukemia activity of Tramesan: a newly identified bioactive fungal metabolite. Oxid Med Cell Longev, 2017; 2017:5061639.

Roca-Lema D, Martinez-Iglesias O, Fernández de Ana Portela C, Rodríguez-Blanco A, Valladares-Ayerbes M, Díaz-Díaz A, Casas-Pais A, Prego C, Figueroa A. In vitro anti-proliferative and anti-invasive effect of polysaccharide-rich extracts from Trametes Versicolor and Grifola frondosa in colon cancer cells. Int J Med Sci, 2019; 16(2):231-40.

Rosendahl AH, Sun C, Wu D, Andersson R. Polysaccharide-K (PSK) increases $\mathrm{p} 21^{\mathrm{WAF} / \mathrm{Cip} 1}$ and promotes apoptosis in pancreatic cancer cells. Pancreatology, 2012; 12(6):467-74

Scarpari M, Reverberi M, Parroni A, Scala V, Fanelli C, Pietricola C, Zjalic S, Maresca V, Tafuri A, Ricciardi MR, Licchetta R, Mirabilii S, Sveronis A, Cescutti P, Rizzo R. Tramesan, a novel polysaccharide from Trametes versicolor. Structural characterization and biological effects. PLoS One, 2017; 12(8):1-22.

Shnyreva AV, Shnyreva AA, Espinoza C, Padrón JM, Trigos Á. Antiproliferative activity and cytotoxicity of some medicinal wooddestroying mushrooms from Russia. Int J Med Mushrooms, 2018, 20(1):1-11.

Suárez A, Gómez L, Soto D, Soto C, Gamboa Ó, Escandón S, Terselich G. Resultados del tratamiento de osteosarcoma convencional de alto grado en niños y adolescentes: análisis de supervivencia de una cohorte tratada sin metotrexato. Rev Colomb de Cancerol, 2017; 21(2):86-94.

Sun Y, Sun T, Wang F, Zhang J, Li C, Chen X, Li Q, Sun S. A polysaccharide from the fungi of Huaier exhibits anti-tumor potential and immunomodulatory effects. Carbohydr Polym, 2013; 92(1):577-82. 
Tian Y, Zhao Y, Zeng H, Zhang Y, Zheng B. Structural characterization of a novel neutral polysaccharide from Lentinus giganteus and its antitumor activity through inducing apoptosis. Carbohydr Polym, 2016; 154:231-40.

Wang KF, Sui K, Guo C, Liu CZ. Improved production and antitumor activity of intracellular protein-polysaccharide from Trametes versicolor by the quorum sensing molecule-tyrosol. J Funct Foods, 2017a; 37:90-6.

Wang KF, Sui KY, Guo C, Liu CZ. Quorum sensing moleculefarnesol increased the production and biological activities of extracellular polysaccharide from Trametes versicolor. Int J Biol Macromol, 2017b; 104:377-83.

Wasser SP. Current findings, future trends, and unsolved problems in studies of medicinal mushrooms. Appl Microbiol Biotechnol, 2011; 89(5):1323-32.

Zhao X, Ma S, Liu N, Liu J, Wang W. A polysaccharide from Trametes robiniophila Murrill induces apoptosis through intrinsic mitochondrial pathway in human osteosarcoma (U-2 OS) cells. Tumour Biol, 2015a; 36(7):5255-63.

Zhao X, Ma S, Liu N, Liu J, Wang W. A polysaccharide from Trametes robiniophila inhibits human osteosarcoma xenograft tumor growth in vivo. Carbohydr Polym, 2015b; 124:157-63.

\section{How to cite this article:}

Muñoz-Castiblanco T, Mejía-Giraldo JC, Puertas-Mejía MA. Trametes genus, a source of chemical compounds with anticancer activity in human osteosarcoma: a systematic review. J Appl Pharm Sci, 2020; 10(10):121-129. 